\title{
Female Reproductive System
}

National Cancer Institute

\section{Source}

National Cancer Institute. Female Reproductive System. NCI Thesaurus. Code C12402.

The collection of org ans and tissues, including the ovaries, genital tract, and breasts, that have several functions, including sexual maturation, pregnancy, and childbirth. 